\title{
CONTROL OF Lasiodiplodia theobromae, THE CAUSAL AGENT OF DIEBACK OF SAPOTE MAMEY [Pouteria sapota (Jacq.) H. E. Moore and Stearn] GRAFTS IN MÉXICO
}

\section{CONTROL DE Lasiodiplodia theobromae, AGENTE CAUSAL DE LA MUERTE DESCENDENTE DE INJERTOS DE ZAPOTE MAMEY [Pouteria sapota (Jacq.) H. E. Moore y Stearn] EN MÉXICO}

\author{
Juan M. Tovar Pedraza ${ }^{1 \star}$, José A. Mora Aguilera ${ }^{1}$, Cristian Nava Díaz ${ }^{1}$, Daniel Téliz Ortiz ${ }^{1}$, \\ Ángel Villegas Monter ${ }^{2}$ y Santos G. Leyva Mir ${ }^{3}$
}

\begin{abstract}
${ }^{1}$ Postgrado en Fitopatología y ${ }^{2}$ Postgrado en Fruticultura, Campus Montecillo, Colegio de Postgraduados. Km 36.5 Carretera México-Texcoco. 56230, Montecillo, Texcoco, Estado de México. ${ }^{3}$ Departamento de Parasitología Agrícola, Universidad Autónoma Chapingo. Km 38.5 Carretera México-Texcoco. 56230, Chapingo, Texcoco, Estado de México.

*Autor para correspondencia (jmtovar@colpos.mx)
\end{abstract}

\section{SUMMARY}

Dieback of sapote mamey [Pouteria sapota (Jacq.) H. E. Moore and Stearn] grafts caused by Lasiodiplodia theobromae significantly reduces the success of grafting in Mexican nurseries. Semi-commercial tests were conducted in a sapote mamey nursery during two grafting seasons to evaluate the effectiveness of a physical treatment (washing) and three chemical treatments (fungicide dip) on scions. Washing reduced disease incidence up to $31 \%$, whereas chemical treatment reduced it up to $62 \%$. The combination of washing and thiabendazole dip resulted in an incidence decrease of $\mathbf{8 1} \%$. Twelve other fungicides were screened in vitro to evaluate mycelial growth inhibition of $L$. theobromae. The pre-formulated mix of cyprodinil + fludioxinil was the most effective fungicide with $\mathrm{EC}_{50}$ value of $0.0043 \mu \mathrm{g} \mathrm{mL}^{-1}$, followed by pyraclostrobin + boscalid, prochloraz and tebuconazole with $\mathrm{EC}_{50}$ values $<0.1 \mu \mathrm{g} \mathrm{mL}^{-1}$, and iprodione and thiabendazole with $\mathrm{EC}_{50}$ values $<1.0 \mu \mathrm{g} \mathrm{mL}^{-1}$. This study provides novel information about strategies for controlling $L$. theobromae infection during the grafting process of sapote mamey and it also showed the effectiveness of several fungicides under in vitro conditions for controlling this plant pathogenic fungus.

Index words: Pouteria sapota, Lasiodiplodia theobromae, fungicides, nursery, propagation.

\section{RESUMEN}

La muerte descendente de varetas injertadas de zapote mamey [Pouteria sapota (Jacq.) H. E. Moore y Stearn] causada por Lasiodiplodia theobromae reduce significativamente el prendimiento de injertos en viveros en México. Se realizaron pruebas semi-comerciales en un vivero de zapote mamey durante dos épocas de injerto para evaluar la efectividad de tratamientos físicos (lavado) y químicos (inmersión en fungicida) en varetas de este frutal. El lavado disminuyó la incidencia de la enfermedad hasta $31 \%$, mientras que, el tratamiento químico la redujo hasta en $62 \%$. La combinación del lavado con thiabendazole abatió la incidencia hasta $81 \%$. Otros doce fungicidas se evaluaron in vitro para inhibir el crecimiento micelial de $L$. theobromae. La mezcla pre-formulada de cyprodinil + fludioxinil fue el fungicida más efectivo con valores de $\mathrm{EC}_{50}=0.0043 \mu \mathrm{g} \mathrm{mL}^{-1}$, seguido por pyraclostrobin + boscalid, prochloraz y tebuconazole con $\mathrm{EC}_{50}<0.1 \mu \mathrm{g} \mathrm{mL}^{-1}$, e iprodione $\mathrm{y}$ thiabendazole con valores $\mathrm{EC}_{50}<1.0 \mu \mathrm{g} \mathrm{mL}^{-1}$. Este estudio provee información novedosa sobre estrategias para controlar a $L$. theobromae durante el proceso de injerto de zapote mamey, además de mostrar la efectividad in vitro de varios fungicidas para el control de este hongo fitopatógeno.
Palabras clave: Pouteria sapota, Lasiodiplodia theobromae, fungicidas, vivero, propagación.

\section{INTRODUCTION}

Lasiodiplodia theobromae (Pat.) Griff. \& Maubl. (syn. Botryodiplodia theobromae Pat.) the anamorphic stage of Botryosphaeria rhodina (Berk. \& M.A. Curtis) Arx, is widely distributed in tropical and subtropical regions and has been associated with approximately 500 hosts. It induces diseases such as dieback, root rot, fruit rot, blights, gummosis, stem necrosis, leaf spot and witches' broom disease (Punithalingam, 1980). The major industrial crops and fruit trees in which it has been found causing pre-harvest (dieback and gummosis) and/or post-harvest (fruit rot) diseases are: avocado (Persea americana Mill.) (Darvas and Kotze, 1987), soursop (Annona muricata L.) (Ponte, 1985), cocoa (Theobroma cacao L.) (Mbenoun et al., 2008), citrus (Citrus spp.) (Adisa and Obinyereokwu, 1988), coconut (Cocos nucifera L.) (Correia and Costa, 2005), guava (Psidium guajava L.) (Cardoso et al., 2002), mango (Mangifera indica L.) (Meah et al., 1991), papaya (Carica papaya L.) (Wang et al., 2007), grapevine (Vitis vinifera L.) (Bester et al., 2007) and sapote mamey (Pouteria sapota (Jacq.) H. E. Moore and Stearn) (Bautista et al., 2002; Gómez et al., 2009; Vásquez et al., 2009). This fungus has also been associated with dieback and necrosis at the grafting site of cashew (Anacardium occidentale L.) (Freire et al., 2002), guava (Cardoso et al., 2002), citrus (Davis et al., 1987), grapevine (Aroca et al., 2008) and sapote mamey (Tovar et al., 2012).

Incidence of $L$. theobromae induced dieback of sapote mamey grafts during grafting is high (> $70 \%)$ in Mexico (Tovar et al., 2012), however, there is no information regarding physical or chemical treatment of vegetative material used in grafting of this fruit.

Fungicides have become the most important means of controlling fungal pathogens. Several in vitro tests have 
determined the sensitivity of $L$. theobromae to fungicides (Bester et al., 2007; Da Silva et al., 2012), however, there are no reports of in vitro tests for the control of $L$. theobromae isolates obtained from sapote mamey.

Based on this information, this study evaluated the potential effect of fungicide dip (chemical treatment) and washing of scions (prophylactic physical treatment) to prevent graft infection by $L$. theobromae during vegetative propagation of sapote mamey and to determine the in vitro effectiveness of a range of fungicides to inhibit mycelial growth of $L$. theobromae.

\section{MATERIALS AND METHODS}

\section{Nursery tests}

Chemical and physical prophylactic treatments were conducted during two grafting seasons (Spring and Fall 2009) in a commercial nursery of sapote mamey located in Alpoyeca, Guerrero, México, using naturally infected scions. Rootstocks were grown from seeds of freshly harvested fruits. Conventional practices of nutrition and irrigation were applied until plants reached $80 \mathrm{~cm}$ in height and a minimum of $2 \mathrm{~cm}$ in diameter over a period of 10 to 12 months. The experimental shoots (straight, $25 \mathrm{~cm}$ long, without physical damage and with several dormant buds and mature leaves) were collected from the tree "El Mexicano", a 20-years-old selection. The scions collected during March and October 2009, were manually defoliated. A total of 256 sapote mamey scions were grafted by the veneer grafting technique as recommended by Villegas and Mora (2008).

Scions were washed by prophylactic physical treatment with a natural fiber and water with the aim to remove dead tissue (pubescence) and organic residues. Water excess was removed with blotting paper; washed scions were allowed to air dry for $15 \mathrm{~min}$ and then grafted.

The prophylactic chemical treatment was dipping scions in the fungicide suspension for $15 \mathrm{~min}$. The following fungicides were tested: thiabendazole $\left(600 \mathrm{mg} \mathrm{L}^{-1}\right)$, mancozeb (800 $\left.\mathrm{mg} \mathrm{L}^{-1}\right)$, and thiabendazole + mancozeb $\left(600 \mathrm{mg} \mathrm{L}^{-1}+\right.$ $800 \mathrm{mg} \mathrm{L}^{-1}$ ). Excess fungicide suspension was removed with blotteing paper, and treated scions were allowed to air dry for $15 \mathrm{~min}$ before grafting.

Washing prior to application of each of the three fungicide dips was performed to determine the interaction between both groups of treatments. Control scions were neither washed nor dipped into the fungicide suspension. The experimental design consisted of four randomized blocks. Each block contained eight treatments. Each treatment was applied on 4 scions. In the whole experiment, each treatment was applied to 16 scions.

All grafts were covered with clear plastic bags to avoid dehydration. Grafted plants were maintained under $75-80$ $\%$ shade cloth, and inspected every week for disease development. The effect of washing and fungicide dip was assessed $30 \mathrm{~d}$ after grafting. Diseased grafted plants for each treatment were taken to the laboratory to confirm the presence of $L$. theobromae. Incidence of diseased grafts for each treatment was calculated with the following equation: $I i=$ $\mathrm{Nni} / \mathrm{Ni}$; where, $\mathrm{Ii}=$ incidence of diseased grafts at the moment $I ; n i=$ number of diseased grafts at the moment $I ; N i=$ total population of grafted plants for each treatment.

\section{In vitro test}

Lasiodiplodia theobromae isolate (GenBank Accession No. JQ245975) used in in vitro screening tests was obtained from a commercial nursery of sapote mamey grafted plants that showed necrosis in the graft union and dieback of scions (Tovar et al., 2012). This isolate is maintained at the culture collection of the herbarium "CMPH" (Accession No. CB007) at Colegio de Postgraduados, Campus Montecillo, Texcoco, Estado de México, México.

Seven systemic and five contact fungicides, representing ten different chemical groups, were selected for the in vitro mycelial growth inhibition tests (Table 1).

Fungicide stock solutions $\left(1000 \mu \mathrm{g} \mathrm{mL}^{-1}\right)$ were made using sterile distilled water. Aliquots of stock solutions were incorporated into autoclaved potato-dextrose-agar (PDA) (BD Bioxon ${ }^{\circledR}$, Becton Dickinson, USA) when the medium was at 45 to $50^{\circ} \mathrm{C}$ to provide concentrations of $0.1,1,10$ and $100 \mu \mathrm{g} \mathrm{mL}^{-1}$. The pre-formulated mix of cyprodinil + fludioxonil was tested at $0.001,0.005,0.01,0.05$, and 0.1 $\mu \mathrm{g} \mathrm{mL} \mathrm{m}^{-1}$. PDA without fungicide was used as control. Approximately $20 \mathrm{~mL}$ of fungicide-amended medium was poured into Petri dishes. Mycelial plugs (5 $\mathrm{mm}$ in diameter) obtained from the margins of actively growing culture (4 days-old) of $L$. theobromae on PDA were transferred to the fungicide-amended plates. Four replicates were used per fungicide concentration. Plates were incubated at $28^{\circ} \mathrm{C}$ and the diameter of radial mycelial growth of each colony was measured perpendicularly twice every $24 \mathrm{~h}$ for $3 \mathrm{~d}$. The complete experiment was repeated twice.

\section{Statistical analysis}

Incidence data of the nursery trials were transformed to arcsine values before the analysis to normalize the variances. Data were subjected to analysis of variance (ANOVA) using SAS (Statistical Analysis System, version 9.1, SAS Institute 
Table 1. Fungicides tested for in vitro mycelial growth inhibition of Lasiodiplodia theobromae, isolated from sapote mamey (Pouteria sapota) grafts with symptoms of dieback.

\begin{tabular}{lcccc}
\hline \multicolumn{1}{c}{ Chemical group } & Active ingredient (a.i) & Action & a. i. (\%) & Formulation \\
\hline Anilinopyrimidines & Pyrimethanil & $\mathrm{S}^{\dagger}$ & 54.6 & SC \\
Anilinopyrimidines/ Phenylpyrroles & Cyprodinil + Fludioxinil & $\mathrm{S}$ & $37.5 / 25$ & WG \\
Benzimidazoles & Thiabendazole & $\mathrm{S}$ & 60 & $\mathrm{WP}$ \\
Chloronitriles & Chlorothalonil & $\mathrm{C}$ & 75 & $\mathrm{WP}$ \\
Dicarboximides & Iprodione & $\mathrm{C}$ & 50 & $\mathrm{WP}$ \\
Dithiocarbamates & Mancozeb & $\mathrm{C}$ & 80 & $\mathrm{WP}$ \\
DMI- Imidazoles & Prochloraz & $\mathrm{S}$ & 42.1 & $\mathrm{EC}$ \\
DMI- Triazoles & Tebuconazole & $\mathrm{S}$ & 25 & EW \\
Inorganic (Copper) & Copper hydroxide & $\mathrm{C}$ & 37.5 & SC \\
Phthalamides & Captan & $\mathrm{C}$ & 50 & $\mathrm{WP}$ \\
QoI- Methoxycarbamates/ Pyridinecarboxamides & Pyraclostrobin + Boscalid & $\mathrm{S}$ & $25.2 / 12.8$ & WG \\
QoI- Oximinoacetates & Kresoxim-methyl & $\mathrm{S}$ & 50 & WG \\
\hline
\end{tabular}

${ }^{{ }^{S} \mathrm{~S}}$ = systemic fungicide; $\mathrm{SC}=$ suspension concentrate; $\mathrm{WG}=$ water dispersible granule; $\mathrm{WP}=$ wettable powder; $\mathrm{C}=$ contact fungicide; $\mathrm{DMI}=\mathrm{demethylation}$ inhibitors; $\mathrm{EC}=$ emulsifiable concentrate; $\mathrm{EW}=$ emulsion oil in water; $\mathrm{QoI}=$ quinone outside inhibitors.

Cary, NC). Treatment means were compared using the least significant difference $(\mathrm{LSD})$ test $(\mathrm{P} \leq 0.05)$. Data from each grafting season were analyzed separately.

Inhibition of mycelial growth for each fungicide concentration of the in vitro tests was calculated as a percentage with respect to the control treatment (un-amended PDA). Percentages of mycelial growth inhibition were converted to Probits and plotted against $\log _{10}$ values of the fungicide concentration. Probit regression analysis was used to calculate the effective concentration values that inhibited mycelial growth by $50 \%$. $\mathrm{EC}_{50}$ values were processed by an ANOVA performed with the General Linear Model (GLM) of SAS and treatment means were separated using the least significant difference (LSD) value at $\mathrm{P} \leq 0.05$.

\section{RESULTS AND DISCUSSION}

\section{Nursery tests}

Washing significantly reduced dieback incidence of grafts during the spring season but not during the fall, as compared to the control (Table 2). In spring, disease incidence decreased from $87.50 \%$ of the control to $56.25 \%$ of the washed scions (a reduction of $31 \%$ ), while in fall the corresponding incidence reduction only was of $18 \%$. This result was probably related to a higher concentration of inoculum during the fall season, as it was shown by Vásquez et al. (2009) who found that the highest concentration of conidia in the air was captured in volumetric traps during the fall seasons from 2007 to 2009 in Alpoyeca, Guerrero.

According to Tovar et al. (2012), L. theobromae inoculum is located in the cortex and trichomes of sapote ma- mey scions; thus, it is presumed that treatment by washing removed the fungal inoculum present on the scions. Hot water treatment is effective in reducing or eradicating the inoculum source of fungal pathogens that cause diseases in grapevine nurseries (Edwards et al., 2004; Halleen et al., 2007).

No significant difference was detected among chemical treatments. However, all chemical treatments significantly reduce disease incidence with values ranging from 37 to $62 \%$ compared to the control during both grafting seasons, respectively (Table 2 and Figure 1). Retief et al. (2006) and Gramaje et al. (2009) showed that dipping of material in fungicide suspension eliminates the inoculum source from the surface and/or decreases superficial fungal growth during the graft union process in grapevine nurseries. No phytotoxicity symptoms were observed with any of the fungicides tested.

The combination of physical and chemical treatments reduced the disease incidence up to $81 \%$, compared with the untreated control scions during both seasons (Table 2). These results coincide with reports by Halleen et al. (2007) in grapevine propagating material, in which the reduction of disease incidence was more consistent in the propagating material that received the combination of physical and chemical treatments. Our results support the statement that an integrated management program is most effective in reducing the incidence of diseases caused by fungal pathogens that penetrate during the grafting process (Fourie and $\mathrm{Ha}-$ lleen, 2005, 2006).

We observed mycelial growth and conidia of $L$. theobromae on the stem cortex, and presumably, it only penetrated 
Table 2. Mean incidence of dieback of sapote mamey grafts, after physical and chemical prophylactic treatments during two grafting seasons in 2009, in Guerrero, México.

\begin{tabular}{lcc}
\hline \multirow{2}{*}{ Treatments } & \multicolumn{2}{c}{ Incidence (\%) } \\
\cline { 2 - 3 } & Spring & $37.50 \mathrm{c}$ \\
\hline Thiabendazole $(\mathrm{T})$ & $25.00 \mathrm{~cd}{ }^{\dagger}$ & $43.75 \mathrm{c}$ \\
Mancozeb $(\mathrm{M})$ & $31.25 \mathrm{c}$ & $56.25 \mathrm{bc}$ \\
Thiabendazole/mancozeb $(\mathrm{T}+\mathrm{M})$ & $43.75 \mathrm{bc}$ & $75.00 \mathrm{ab}$ \\
Washing $(\mathrm{W})$ & $56.25 \mathrm{~b}$ & $12.50 \mathrm{~d}$ \\
$\mathrm{~W}+\mathrm{T}$ & $6.25 \mathrm{~d}$ & $37.50 \mathrm{c}$ \\
$\mathrm{W}+\mathrm{M}$ & $6.25 \mathrm{~d}$ & $50.00 \mathrm{c}$ \\
W $+(\mathrm{T}+\mathrm{M})$ & $31.25 \mathrm{c}$ & $93.75 \mathrm{a}$ \\
Control (without treatment) & $87.50 \mathrm{a}$ & \\
\hline
\end{tabular}

${ }^{\dagger}$ Means with the same letter in a column are not significantly different (LSD, 0.05).

through deep and extensive wounds, such as the ones made to scions and rootstocks during the grafting process. However, the inoculum was effectively removed by washing and by treating with the fungicide dip, especially with thiabendazole. These findings suggest that the combination of washing and chemical treatments should be recommended to prevent infections by $L$. theobromae in grafts and increase the success of young plants established in sapote mamey orchards.

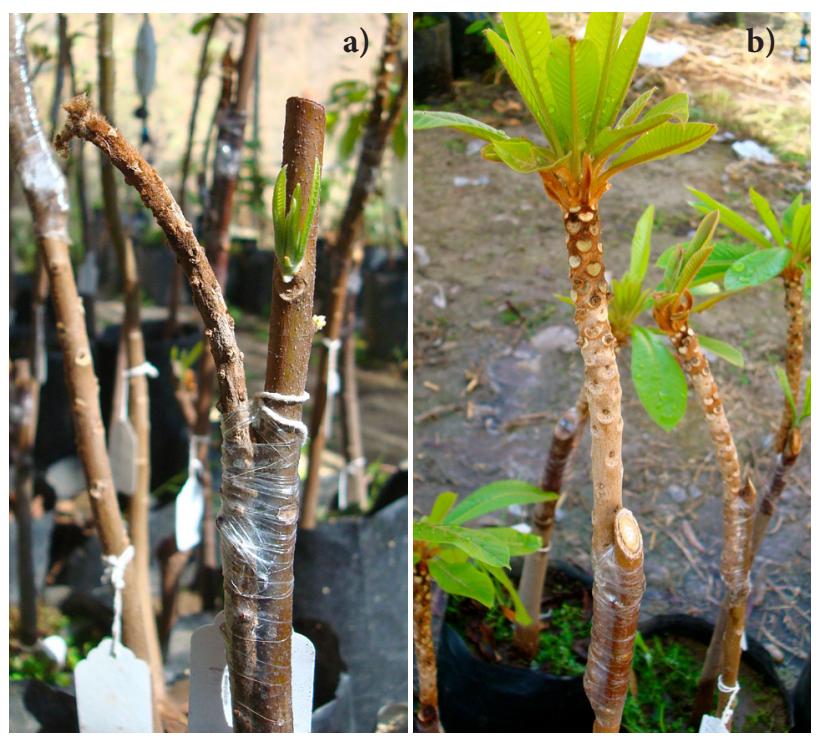

Figura 1. Effect of washing and chemical treatments on sapote mamey scions, $30 \mathrm{~d}$ after grafting. a) Dead untreated scion; b) Healthy treated scion.

\section{In vitro test}

Mycelial growth assay. The pre-formulated mix of cyprodinil + fludioxinil was the most effective fungicide in reducing mycelial growth with $\mathrm{EC}_{50}$ value $=0.0043 \mu \mathrm{g} \mathrm{mL}^{-1}$
(Table 3). Similarity, Wang et al. (2007) found that the mix of cyprodinil + fludioxinil inhibited mycelial growth of $L$. theobromae isolates from papaya to $\mathrm{EC}_{50}=0.0073 \mu \mathrm{g} \mathrm{mL}^{-1}$.

The $\mathrm{EC}_{50}$ values of pyraclostrobin + boscalid, prochloraz, and tebuconazole ranged from 0.014 to $0.048 \mu \mathrm{g} \mathrm{mL}^{-1}$, followed by iprodione and thiabendazole $\left(\mathrm{EC}_{50}=0.335\right.$ to $\left.0.430 \mu \mathrm{g} \mathrm{mL}^{-1}\right)$. Wang et al. (2007) found prochloraz, iprodione, and tebuconazole as the most effective fungicides to inhibit mycelial growth of $L$. theobromae isolates from papaya with $\mathrm{EC}_{50}<1 \mu \mathrm{g} \mathrm{mL} \mathrm{m}^{-1}$. In contrast, Da Silva et al. (2012) indicated that thiabendazole, prochloraz, and tebuconazole were effective with $\mathrm{EC}_{50}$ values $>1 \mu \mathrm{g} \mathrm{mL}^{-1}$; however, their isolates were obtained from papaya orchards subjected to several fungicide applications. Bester et al. (2007) reported that prochloraz and tebuconazole at low $\mathrm{EC}_{50}(<0.6 \mu \mathrm{g}$ $\mathrm{mL}^{-1}$ ) inhibited mycelial growth of $L$. theobromae isolates from grapevines, while kresoxim-metyl, iprodione and pyrimethanil were ineffective. Our results coincide with this report, except for iprodione, which, in this study, was observed to be effective with an $\mathrm{EC}_{50}$ value $=0.335 \mu \mathrm{g} \mathrm{mL}^{-1}$.

In this in vitro test, systemic fungicides were effective at low concentrations because our $L$. theobromae isolate had not been previously exposed to selection pressure by fungicide application in sapote mamey nurseries or orchards. Most of the contact fungicides (captan, chlorothalonil, copper hydroxide, and mancozeb) inhibited mycelial growth

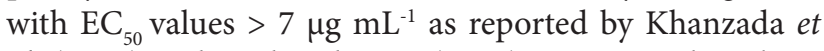
al. (2005) and Gud and Raut (2008) in tests with isolates from mango.

We selected contact and systemic fungicides from different chemical groups, because the fungicide application programs that prevent pathogen populations from developing fungicide resistance are based on the rotation and/ or combination of two action types (Denman et al., 2004). 
Table 3. $\mathrm{EC}_{50}$ values for in vitro inhibition of mycelial growth of $L$. theobromae in PDA culture, by fungicides representing different chemical groups.

\begin{tabular}{lcc}
\hline & & $\mathrm{EC}_{50}\left(\mu \mathrm{g} \mathrm{mL}^{-1}\right)$ \\
\hline & Range & Mean \\
\hline Captan & $(9.2500-16.955)$ & $12.340 \mathrm{a}^{\dagger}$ \\
Cyprodinil + fludioxinil & $(0.0035-0.0056)$ & $0.0043 \mathrm{e}$ \\
Chlorothalonil & $(5.0625-12.033)$ & $7.598 \mathrm{~b}$ \\
Copper hydroxide & $(7.5325-12.285)$ & $9.590 \mathrm{~b}$ \\
Iprodione & $(0.2450-0.448)$ & $0.335 \mathrm{~d}$ \\
Kresoxim-methyl & $(2.4925-5.140)$ & $3.413 \mathrm{c}$ \\
Mancozeb & $(6.0350-9.143)$ & $7.448 \mathrm{~b}$ \\
Pyrimethanil & $(1.4000-2.318)$ & $1.800 \mathrm{~cd}$ \\
Prochloraz & $(0.0050-0.035)$ & $0.015 \mathrm{~d}$ \\
Pyraclostrobin + boscalid & $(0.0019-0.045)$ & $0.014 \mathrm{~d}$ \\
Tebuconazole & $(0.0175-0.090)$ & $0.048 \mathrm{~d}$ \\
Thiabendazole & $(0.3275-0.558)$ & $0.430 \mathrm{~d}$ \\
\hline
\end{tabular}

${ }^{\dagger}$ Means with the same letter in a column are not significantly different (LSD, 0.05).

Cyprodinil + fludioxinil, pyraclostrobin + boscalid, prochloraz, tebuconazole and iprodione showed high effectiveness against $L$. theobromae and should be evaluated in additional trials in sapote mamey nurseries to confirm their efficacy in the field.

\section{CONCLUSIONS}

The combination of washing with water and fungicide dip was effective to prevent infections by $L$. theobromae during the grafting process of sapote mamey. Cyprodinil + fludioxinil, pyraclostrobin + boscalid, prochloraz, tebuconazole and iprodione effectively inhibited mycelial growth of $L$. theobromae in vitro.

\section{ACKNOWLEDGMENTS}

This research was financially supported by Fundación Produce de Guerrero, México (Project PM 1731). The authors gratefully acknowledge Dr. Luciano Martínez Bolaños and M.Sc. Lauro Soto Rojas for their helpful suggestions in the statistical analysis.

\section{BIBLIOGRAPHY}

Adisa V A, O A Obinyereokwu (1998) Studies on the latent infection of Botryodiplodia theobromae Pat. on Citrus sinensis (Li.) Osbeck fruit. Mycopathologia 102:165-167.

Aroca A, R Raposo, D Gramaje, J Armengol, S Martos, J Luque (2008) First report of Lasiodiplodia theobromae on rootstocks mother grapevines in Spain. Plant Dis. 92:832.

Bautista B S, J C Díaz P, L L Barrera N (2002) Postharvest fungal rots of sapote mamey Pouteria sapota H. E. Moore \& Stearn. Postharv.
Biol. \& Technol. 24:197-200.

Bester W, P W Crous, P H Fourie (2007) Evaluation of fungicides as potential grapevine pruning wound protectants against Botryosphaeria species. Austral. Plant Pathol. 36:73-77.

Cardoso J E, C M Maia, M N G Pesso (2002) Occurrence of Pestalotiopsis psidii and Lasiodiplodia theobromae causing stem rot of guava plants in the State of Ceará, Brazil. Fitopatol. Brasil. 27:320.

Correia M S, J L S Costa (2005) Dispersão anemófila do fungo Lasiodiplodia theobromae em plantações de coqueiro. Fitopatol. Brasil. 30:150-154.

Da Silva P A V, R B Martins, S J Michereff, M B Da Silva, M P S Câmara (2012) Sensitivity of Lasiodiplodia theobromae from Brazilian papaya orchards to MBC and DMI fungicides. Eur. J. Plant Pathol. 132:489-498.

Darvas J M, J M Kotze (1987) Fungi associated with pre- and postharvest diseases of avocado fruit at Westfalia, South Africa. Phytophylactica 19:83-85.

Davis R M, C J Farrald, D Davila (1987) Botryodiplodia trunk lesions in Texas citrus. Plant Dis. 71:848-849.

Denman S, P W Crous, A Sadie, M J Wingfield (2004) Evaluation of fungicides for the control of Botryosphaeria protearum on Protea magnifica in the Western Cape Province of South Africa. Austral. Plant Pathol. 33:97-102.

Edwards J, I G Pascoe, S Salib, N Laukart (2004) Hot treatment of grapevine cuttings reduces incidence of Phaeomoniella chla mydospora in young vines. Phytopathol. Med. 43: 158-159.

Fourie P H, F Halleen (2005) Integrated strategies for proactive management of grapevine trunk diseases in nurseries. Phytopathol. Med. 44:111.

Fourie P H, F Halleen (2006) Chemical and biological protection of grapevine propagation material from trunk disease pathogens. Eur. J. Plant Pathol. 116:255-265.

Freire F C O, J E Cardoso, A A dos Santos, F M P Viana (2002) Diseases of cashew nut plants (Anacardium occidentale L.) in Brazil Crop Prot. 21:489-494.

Gómez J R, D Nieto A, D Téliz O, J A Mora A, M T Martínez D, M Vargas H (2009) Manejo postcosecha y hongos asociados a la pudrición del fruto de zapote mamey (Pouteria sapota) en Guerrero, México. Agrociencia 43:37-48.

Gramaje D, A Aroca, R Raposo, J García J, J Armengol (2009) Evaluation of fungicides to control Petri disease pathogens in the grapevine propagation process. Crop Prot. 28:1091-1097. 
Gud M A, S P Raut (2008) Control of mango anthracnose and stem-end rot fungi by fungicides and bio-agents. J. Mahar. Agric. Univ. 33:120-122.

Halleen F, P H Fourie, P W Crous (2007) Control of black foot disease in grapevine nurseries. Plant Pathol. 56:637-645.

Khanzada A M, A M Lodhi, S Shaazad (2005) Chemical control of Lasiodiplodia theobromae, the causal agent of mango decline in Sidh. Pakistan J. Bot. 37:1023-1030.

Mbenoun M, Z E H Momo, G Samuels, A F Nsouga, S Nyasse (2008) Dieback due to Lasiodiplodia theobromae, a new constraint to cocoa production in Cameroon. Plant Pathol. 57:381.

Meah M B, R A Plumbley, M J Jeger (1991) Growth and infectivity of Botryodiplodia theobromae causing stem-end rot of mango. Mycol. Res. 95:405-408.

Ponte J J (1985) Uma nova doença da ateira e da gravioleira, causada por Botryodiplodia theobromae. Fitopatol. Brasil. 10:689-691.

Punithalingam E (1980) Plant diseases attributed to Botryodiplodia theobromae Pat. J. Cramer, Vaduz. Biblio. Mycol. 71:1-123.
Retief E, A Mcleod, P H Fourie (2006) Potential inoculum sources of Phaeomoniella chlamydospora in South African grapevine nurseries. Eur. J. Plant Pathol. 115:331-339.

Tovar P J M, J A Mora A, C Nava D, D Téliz O, G Valdovinos P, A Villegas M, J Hernández M (2012) Identification, pathogenicity, and histopathology of Lasiodiplodia theobromae on mamey sapote grafts in Guerrero, Mexico. Agrociencia 46:146-161.

Vásquez L A, J A Mora A, E Cárdenas S, D. Téliz O (2009) Etiología e histopatología de la muerte descendente de árboles de mamey (Pouteria sapota (Jacq.) H. E. Moore and Stearn) en Guerrero, México. Agrociencia 43:717-728.

Villegas M A, J A Mora A (2008) Propagación vegetativa del zapote mamey. In: El Zapote Mamey en México: Avances de Investigación. I Alia T, A Villegas M, V López M, M Andrade R, C M Acosta D, O G Villegas T, D Guillén S (eds). Universidad Autónoma del Estado de Morelos. Morelos, México. pp:1-16.

Wang H L, P H Chen, H F Ni, R S Chen (2007) Physiological characterization and screen of control chemicals for Lasiodiplodia theobromae of papaya. Plant Pathol. Bull. 16:71-77. 